ThIs international multicentre, open-label, parallel-group trial was undertaken to compare the therapeutic efficacy and tolerability of topical levocabastine and oral cetirizine in patients with perennial allergic rhinoconjunctivitis, with particular reference to the comparative onset of action of the two drugs. A total of 207 patients were randomized to receive either levocabastine nasal spray $(0.5 \mathrm{mg} / \mathrm{ml}$, two sprays in each nostril twice daily) plus levocabastine eye drops as required $(0.5 \mathrm{mg} / \mathrm{ml}$, one drop in each eye twice daily p.r.n.) or cetirizine orally $(10 \mathrm{mg}$ once daily) with a treatment duration of 2 weeks. Onset of action was found to be significantly more rapid with levocabastine than with cetirizine for both nasal and ocular symptoms $(p<$ 0.001). Within $15 \mathrm{~min}$ of study drug administration, $36 \%$ of levocabastine-treated patients reported relief from nasal symptoms and 32\% relief from ocular symptoms compared with $10 \%$ and $17 \%$ of patients on cetirizine, respectively. At $1 \mathrm{~h}$, the percentages of patients reporting relief were $76 \%$ and $38 \%$ for nasal symptoms, and $81 \%$ and $48 \%$ for ocular symptoms in the levocabastine and cetirizine treatment groups, respectively. At $8 \mathrm{~h}$ there were no differences between the two treatments. Overall therapeutic efficacy was found to be comparable in the two treatment groups over the 2-week study period with no significant intergroup differences in symptom severity or global therapeutic efficacy. Both drugs were well tolerated with no significant differences in the incidence or type of adverse reactions between the two groups. In conclusion, levocabastine eye drops and nasal spray are as effective and well tolerated as oral cetirizine for the treatment of perennial allergic rhinoconjunctivitis with the advantage of a significantly faster onset of action for both nasal and ocular symptoms.

Key words: Allergic rhinoconjunctivitis, Cetirizine, $\mathrm{H}_{1}$ receptor antagonist, Levocabastine, Topical antihistamine

\section{Faster onset of action with topical levocabastine than with oral cetirizine}

\author{
Michel A. Drouin, ${ }^{1, C A}$ William H. Yang ${ }^{1}$ and \\ Frederick Horak ${ }^{2}$ \\ ${ }^{1}$ Section of Allergy and Clinical Immunology, \\ Department of Medicine, Ottawa Civic Hospital, \\ University of Ottawa, Ottawa, Canada; \\ ${ }^{2}$ ENT Clinic, University of Vienna, Vienna, Austria \\ ${ }^{\mathrm{CA}}$ Corresponding Author
}

\section{Introduction}

Levocabastine is a new $\mathrm{H}_{1}$-receptor antagonist which has been specifically developed for topical ocular and nasal administration. ${ }^{1}$ Preliminary placebo-controlled studies have shown that levocabastine has an extremely rapid onset of action with effects reported within minutes of application. $^{2-4}$ Furthermore, levocabastine has a sufficiently long duration of action to permit a twicedaily dosing regimen. ${ }^{5}$ Comparative clinical trials have shown that topical levocabastine is well tolerated and at least as effective as the oral antihistamines terfenadine and loratadine for the treatment of seasonal allergic rhinoconjunctivitis. $^{6-10}$

(C) 1995 Rapid Communications of Oxford Ltd
This study was undertaken to assess the therapeutic efficacy and tolerability of levocabastine nasal spray and eye drops with those of the second generation oral antihistamine cetirizine in patients with perennial allergic rhinoconjunctivitis with particular reference to the comparative onset of action of the two drugs. While it is to be expected that a topical agent will have a more rapid onset of action than an orally administered drug, no direct comparison of the onset of action of topical levocabastine and an oral antihistamine has been undertaken to date. The present study was set up as an open, randomized comparative trial. The decision to perform this study in an open fashion was deliberate. Experience in previous studies has shown that the 
placebo effect with a topical formulation is substantial, ${ }^{1}$ and considerably higher than that seen with oral study medication. This can be explained by the fact that the instillation of fluid in the nose or (in particular) the eyes might dilute or wash away the allergen. Results of a recent international, double-blind study undertaken to compare levocabastine nasal spray and eye drops with oral terfenadine (using topical placebo dummies in the terfenadine treatment group and oral dummies in the levocabastine treatment group) demonstrate the two approaches to be equally effective, with an overall response for nasal symptoms of $60 \%$ on levocabastine and $63 \%$ on terfenadine and for ocular symptoms of $80 \%$ with levocabastine and $72 \%$ with terfenadine. ${ }^{6}$ Therefore, in order to assess the 'real-life' difference in efficacy between topical and oral antihistamine treatment more accurately, in view of the important topical placebo effect, an open, randomized study design was considered appropriate for this trial.

\section{Material and Methods}

Patients: Patients between the age of 12 and 70 years with at least a 1-year history of perennial allergic rhinoconjunctivitis severe enough to warrant anti-allergy therapy and a positive skin prick test and/or radioallergosorbent (RAST) for a non-seasonal allergen such as house dust mite were eligible for inclusion into this trial. In addition, patients were required to have at least two typical symptoms of perennial allergic rhinoconjunctivitis of moderate severity at the time of entry into the trial. The trial was performed out of the hay fever season (October 11992 to April 30 1993).

Exclusion criteria included: concurrent disease which might complicate evaluation of the study drugs such as vasomotor rhinitis, rhinitis medicamentosa, active infective sinusitis, upper respiratory tract infections and large, obstructive nasal polyps; use of an investigational drug within 30 days prior to entry into the trial; concomitant therapy with any medication which might interfere with the assessment of the study drugs with a washout period of 1 month for systemic corticosteroids, 2 weeks for topical corticosteroids and sodium cromoglycate, 1 week for all antihistamines with the exception of astemizole for which a wash-out period of 6 weeks was required, and 3 days for decongestants and all other ocular and nasal medication; hyposensitization therapy which had varied within 6 months of randomization; and use of soft contact lenses. Pregnant, nursing and fertile women without adequate contraception and patients with concurrent serious cardiovascular, pulmonary, neurological, renal, hepatic or malignant disease were also ineligible for participation in this study.

Study design: This was an international (Austria, Belgium, Canada, Denmark and The Netherlands), multicentre, open-label, parallel-group trial. Patients were randomized to receive either levocabastine nasal spray $(0.5 \mathrm{mg} / \mathrm{ml}$ two puffs in each nostril twice daily) plus levocabastine eye drops as required $(0.5 \mathrm{mg} / \mathrm{ml}$ one drop in each eye twice daily p.r.n.) or cetirizine orally $(10 \mathrm{mg}$ once daily) with a treatment duration of 2 weeks. The study was conducted in accordance with the Declaration of Helsinki and subsequent revisions. The study protocol was approved by the local ethics committee and all patients gave their written informed consent, with informed parental consent required for subjects aged less than 18 years.

Assessments and evaluations: To permit evaluation of onset of action, patients were requested to record the overall severity of both nasal and ocular symptoms on a diary card using a $100 \mathrm{~mm}$ visual analogue scale (VAS; extremes: $0=$ absent, $100=$ very severe) immediately before taking the first dose of study medication and then at 5, 10, 20, 30 and $40 \mathrm{~min}$, and 1, 2, 3, 4, 6, and $8 \mathrm{~h}$ after administration. In addition, patients were requested to indicate how soon they felt significant improvement in nasal and ocular symptom severity following administration of the first dose of study medication, rating onset of action as occurring at $<5 \mathrm{~min}, 5$ to $15 \mathrm{~min}, 15$ to $30 \mathrm{~min}$ or 30 to $60 \mathrm{~min}$ following study drug administration.

To permit assessment of therapeutic efficacy, the severity of rhinorrhoea, sneezing, nasal itching, nasal congestion and ocular symptoms were assessed by the investigator at the start of the trial and at the end of the 2-week treatment period using a 4-point scale $(0=$ none, $1=$ mild [noticeable on occasion but not bothersome], 2 = moderate [noticeable from time to time and tends to be bothersome]; 3 = severe [frequently noticeable and bothersome]). In addition, the same symptoms were assessed by the patients on a daily basis using the same scale and recorded in their diaries. Patients also provided a VAS rating of the overall severity of rhinoconjunctivitis each day. At the end of the trial, both the investigator and the patient provided a global evaluation of treatment efficacy rating therapy as excellent, good, fair or poor.

Any adverse events experienced during the trial were recorded by the patients in their diaries. 
Statistical analysis: An intention-to-treat analysis was performed. Onset of action for both nasal and ocular symptoms was derived from the patients' diary data generated following administration of the first dose of study medication. In addition to the individual symptoms listed above, the sum of all nasal symptoms and the sum of all symptoms were analysed at the start of the trial and at the end of the 2-week treatment period. The area under the curve (AUC) was expressed as a percentage of the maximal AUC and calculated using the trapezoidal rule, the percentage of days with severe symptoms and the percentage of symptom-free days were also determined for all parameters recorded in the patients' diaries. All intergroup differences were subjected to analysis of variance testing (ANOVA).

\section{Results}

A total of 207 patients participated in this trial, 105 in the levocabastine group and 102 in the group which received cetirizine. The two treatment groups were well matched for the major demographic characteristics and symptom severity at baseline as indicated in Tables 1 and 2 . Compliance with the study regimen was found to be comparable in the two treatment groups. The frequency of use of levocabastine eye drops by
Table 1. Baseline demography in the two treatment groups

\begin{tabular}{lll}
\hline & Levocabastine & \multicolumn{1}{c}{ Cetirizine } \\
\hline Number of patients (M/F) & $105(57 / 48)$ & $102(57 / 45)$ \\
Mean age in years (range) & $29.4(11-65)$ & $33.7(12-69)$ \\
Mean weight in kg (range) & $69.9(40-119)$ & $70.0(41-115)$ \\
\hline
\end{tabular}

Table 2. Investigator assessments of symptom severity at baseline and at the end of the trial*

\begin{tabular}{lccccc}
\hline & \multicolumn{2}{c}{ Levocabastine } & & \multicolumn{2}{c}{ Cetirizine } \\
\cline { 2 - 3 } \cline { 5 - 6 } & Baseline & Endpoint & & Baseline & Endpoint \\
\hline Sneezing & 1.7 & 0.5 & & 1.6 & 0.6 \\
Rhinorrhoea & 1.9 & 0.8 & & 1.9 & 0.7 \\
Nasal itching & 1.5 & 0.6 & & 1.4 & 0.5 \\
Nasal congestion & 2.0 & 1.2 & & 2.0 & 0.9 \\
Ocular symptoms & 1.2 & 0.4 & & 1.2 & 0.5 \\
Total nasal symptoms & 7.1 & 3.0 & & 6.9 & 2.6 \\
Total all symptoms & 8.2 & 3.4 & & 8.2 & 3.1 \\
\hline
\end{tabular}

"Each symptom was assessed using a 4-point scale $(0=$ none, $1=$ mild 2 = moderate, $3=$ severe)

patients in the levocabastine treatment group was found to be relatively high. In all, 56 levocabastine-treated patients used the eye drops on $83.7 \%$ of study days.

Three patients in each group failed to complete the study. Three levocabastine-treated patients and one cetirizine recipient withdrew
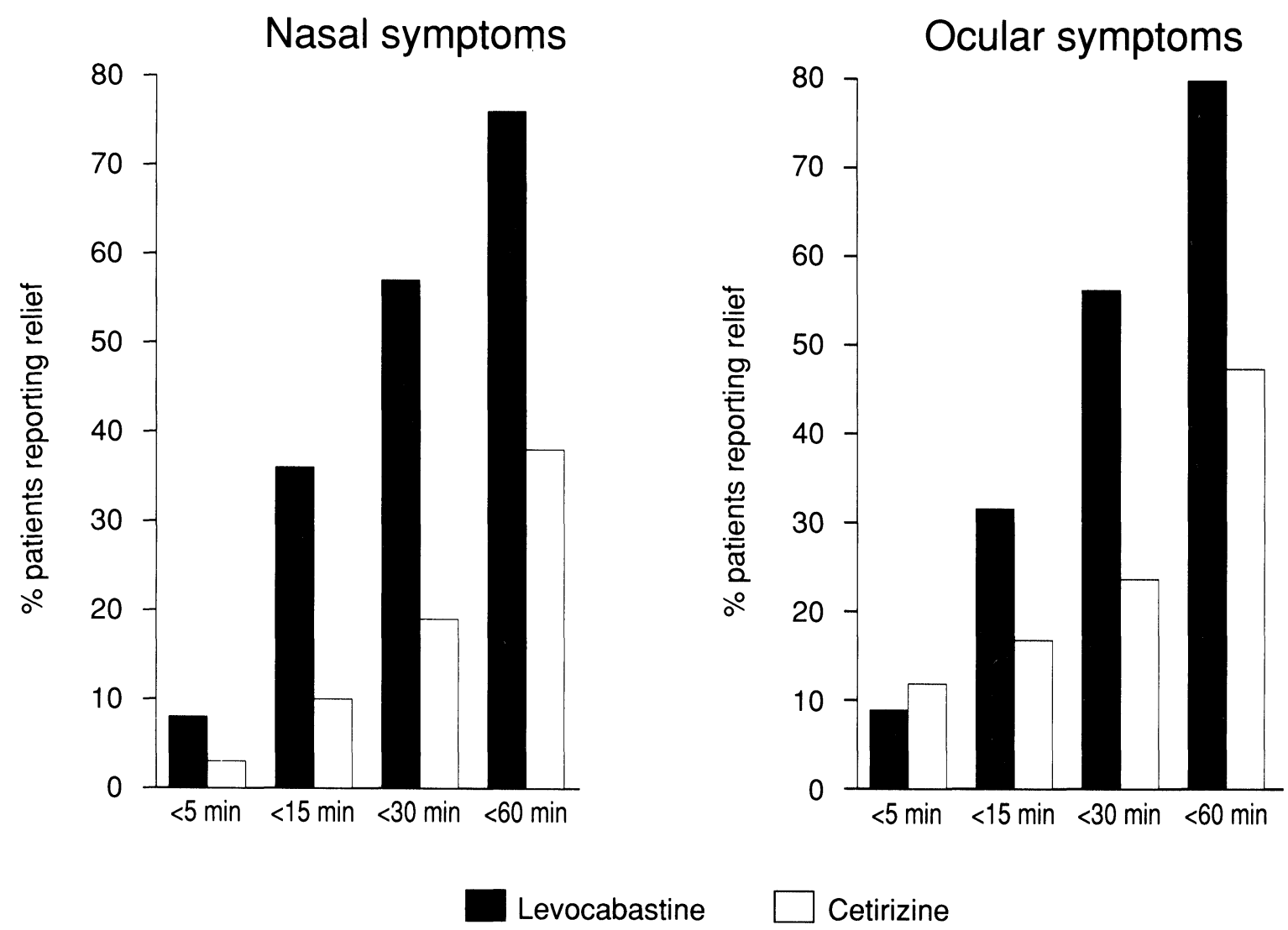

FIG. 1. Onset of action for nasal and ocular symptoms in the two treatment groups. 

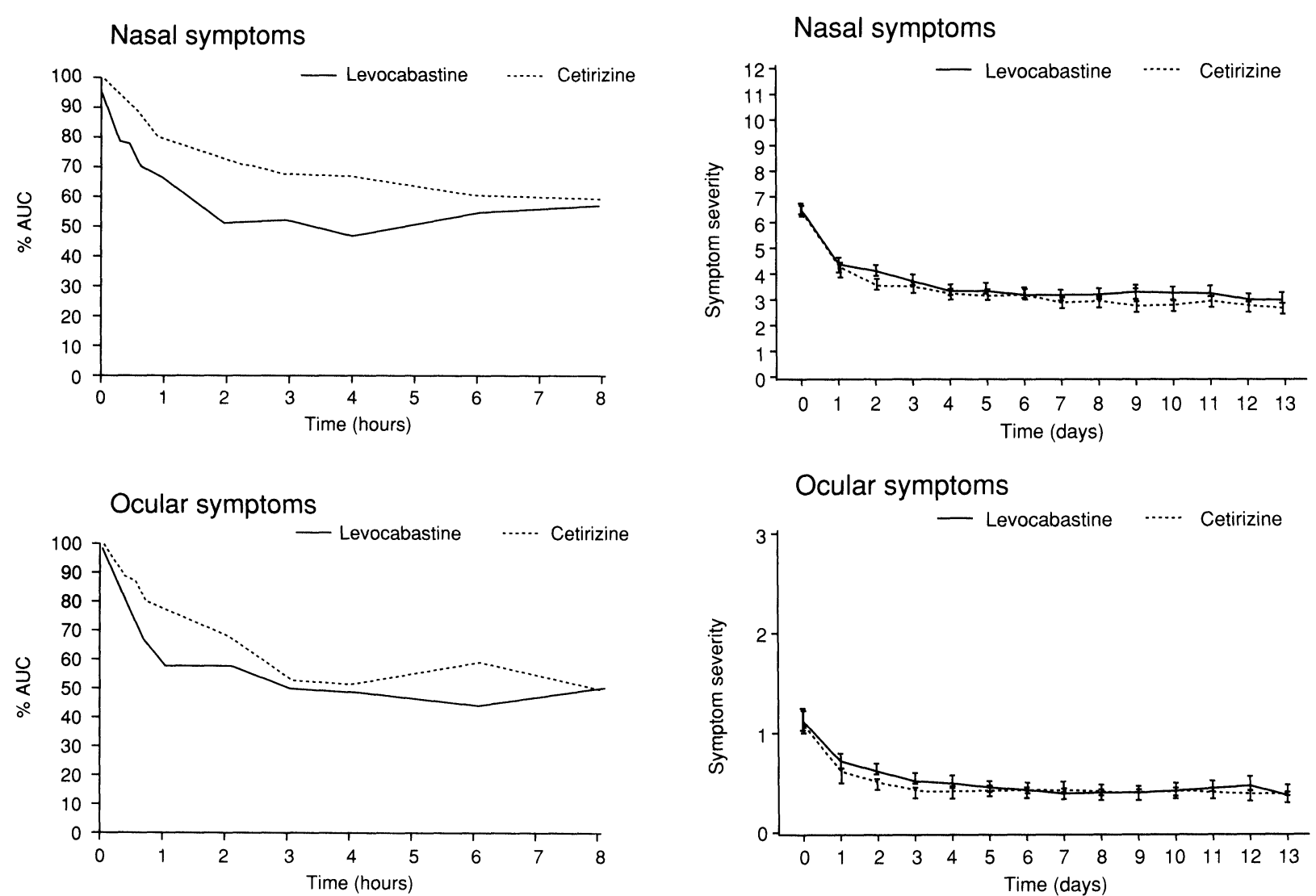

FIG. 2. Patients' VAS ratings of nasal and ocular symptom severity (expressed as \% AUC) over the 8-h period following administration of the first dose of study medication.

due to adverse experiences, one cetirizine-treated patient was lost to follow-up and another withdrawn due to a treatment deviation. Adverse events resulting in withdrawal were headache, sore throat, fatigue and nasal irritation in the levocabastine treatment group and eyelid oedema in the cetirizine group.

Onset of action for both nasal and ocular symptoms was found to be significantly more rapid in levocabastine-treated patients than in those who received cetirizine $(p<0.001)$. In all, $8 \%$ of levocabastine-treated patients reported relief from nasal symptoms within less than 5 min of application of the first dose compared with $3 \%$ of cetirizine recipients, with onset of action within $15 \mathrm{~min}$ reported in $36 \%$ of patients in the levocabastine treatment group and $10 \%$ of those treated with cetirizine. At $30 \mathrm{~min}$, the corresponding values were $57 \%$ and $19 \%$ in the two groups, respectively, with onset of action reported within $1 \mathrm{~h}$ for $76 \%$ of levocabastine-treated patients and 38\% of those on cetirizine. The corresponding values for relief of ocular symptoms were $9 \%$ and $12 \%$ at $5 \mathrm{~min}, 32 \%$ and $17 \%$ at 15 $\mathrm{min}, 57 \%$ and $24 \%$ at $30 \mathrm{~min}$, and $81 \%$ and $48 \%$ at $1 \mathrm{~h}$, in the levocabastine and cetirizine groups respectively (Fig. 1).

FIG. 3. Patient evaluations of nasal and ocular symptom severity during the 2-week trial. Each symptom was scored on a scale of $0-3$. The four nasal symptoms have been combined to give a total symptom score.

Analysis of the AUCs for the patients' VAS ratings of nasal and ocular symptom severity over the 8-h period following administration of the first dose of study medication confirms the patients' reports of symptom relief with time. The median change in the VAS scores from baseline was greater in levocabastine-treated patients than in those who received cetirizine with intergroup differences most marked during the first 2 $\mathrm{h}$ after study drug administration (Fig. 2). At $8 \mathrm{~h}$ there were no differences between the two treatments.

Investigator assessments revealed a comparable reduction in symptom severity in the two treatment groups over the 2-week study period (Table 2). Similarly, no significant intergroup differences were observed between levocabastine and cetirizine for the patient assessments of individual symptom severity (Fig. 3) and VAS ratings of the overall severity of rhinoconjunctivitis. The percentage of symptom-free days and the percentage of days with severe symptoms were also found to be similar in the two treatment groups.

The results of the global evaluations of therapeutic efficacy showed no statistically significant differences between the two drugs. At the end of the trial, the investigator rated the effect of 


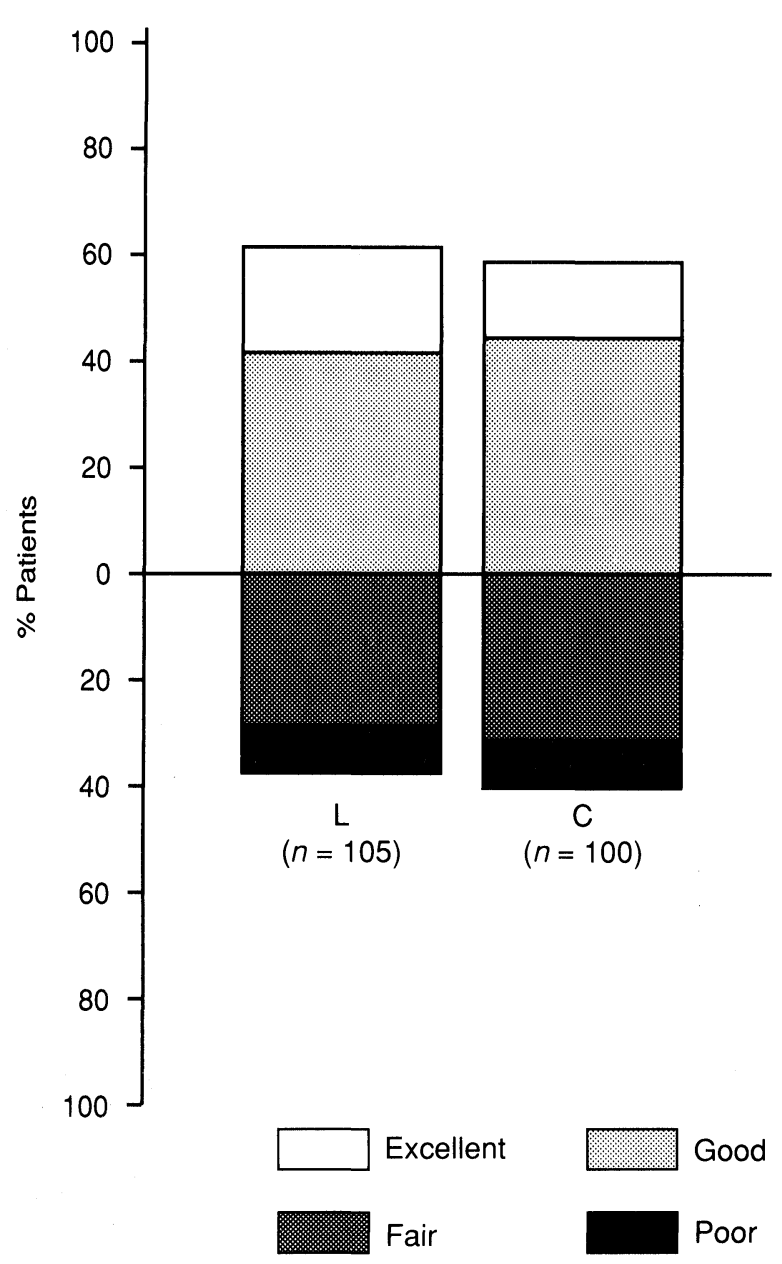

FIG. 4. Investigator evaluations of global therapeutic efficacy at the end of the 2-week treatment period $(L=$ levocabastine; $C=$ cetirizine).

therapy to be excellent or good in $62 \%$ of levocabastine-treated patients and 59\% of the cetirizine group (Fig. 4). The corresponding values

Table 3. Adverse experiences ${ }^{\star}$

\begin{tabular}{lcccr}
\hline & \multicolumn{4}{c}{ Trial group } \\
\cline { 2 - 5 } & Levocabastine & \multicolumn{2}{c}{ Cetirizine } \\
& $n$ & $\%$ & $n$ & $\%$ \\
\hline Total number of patients & 105 & & 100 \\
Total number of patients & 25 & & 20 & \\
reporting an adverse & & & & \\
experience & & & & \\
Adverse experience & 6 & 5.7 & 1 & 1.0 \\
$\quad$ Application site reaction & 5 & 4.8 & 2 & 2.0 \\
Common cold symptoms & 5 & & 3 & 3.0 \\
Dyspepsia & 3 & 2.9 & 1 & 1.0 \\
Epistaxis & & & 2 & 2.0 \\
Eyelid oedema & 2 & 1.9 & 4 & 4.0 \\
Fatigue & 5 & 4.8 & 5 & 5.0 \\
Headache & 2 & 1.9 & & \\
Pharyngitis & 4 & 3.8 & & \\
Rhinitis & 1 & 1.0 & 4 & 4.0 \\
$\quad$ Somnolence & & & & \\
\hline
\end{tabular}

*Adverse experiences occurring in at least two patients per treatment group. for the patient evaluations were $61 \%$ and $62 \%$ in the two groups, respectively.

Adverse experiences (as noted by either the investigator or the patient) were reported by 25 patients (24\%) in the levocabastine group and 20 (20\%) of those who received cetirizine. A wide range of adverse reactions was reported (Table 3 ), the most common being application site reaction (usually mild burning or prickling sensation in the eyes or nose; in $6 \%$ of levocabastinetreated patients and 1\% of cetirizine patients), common cold symptoms ( $5 \%$ of patients in the levocabastine group and $2 \%$ of patients in the cetirizine group), headache ( $5 \%$ of patients in each group), fatigue and somnolence (each reported by $4 \%$ of cetirizine-treated patients, and by $2 \%$ and $1 \%$ of levocabastine-treated patients, respectively). No statistically significant intergroup differences in the incidence or type of adverse reactions were observed.

\section{Discussion}

Second generation, oral $\mathrm{H}_{1}$-receptor antagonists such as cetirizine are widely considered to be a first-line therapeutic option for the treatment of perennial allergic rhinoconjunctivitis. ${ }^{11}$ The therapeutic efficacy of cetirizine for the treatment of this common condition is well documented. $^{12,13}$ The present study was undertaken to compare the efficacy and tolerability of cetirizine given once daily with those of a recently developed topical $\mathrm{H}_{1}$-receptor antagonist, levocabastine, given twice daily with particular reference to the comparative onset of action of the two drugs.

The reports from subjects of how soon they felt significant improvement in their symptoms demonstrate that onset of action was significantly more rapid in levocabastine-treated patients than in those who received cetirizine for both nasal and ocular symptoms $(p<0.001)$. Analysis of the AUCs for patient VAS ratings of nasal and ocular symptom severity over the 8 -h period following administration of the first dose of study medication confirms a faster onset of action for levocabastine.

No significant differences in overall therapeutic efficacy were reported with a comparable reduction in symptom severity observed over the 2 week period in the two treatment groups. Investigator assessments at the end of the study revealed an excellent or good response to therapy in $62 \%$ of levocabastine-treated patients compared with $59 \%$ for patients treated with cetirizine. In all, $61 \%$ of patients in the levocabastine group and $62 \%$ of those on cetirizine reported the effect of therapy to be excellent or good. 
This is in keeping with the results of previous studies which have shown that levocabastine eye drops and nasal spray are at least as effective as the oral antihistamines terfenadine and loratadine for the treatment of seasonal allergic rhinoconjunctivitis, ${ }^{6-10}$ although statistically significant differences in therapeutic efficacy in favour of topical levocabastine were reported for some parameters in two of these trials.

Both drugs were found to be well tolerated with no statistically significant intergroup differences in the incidence or type of adverse experiences reported. Application site reaction was the most common adverse event reported in levocabastine-treated patients in this study, with an incidence of $6 \%$. Previous studies have shown that the incidence of local irritation following topical administration of levocabastine is comparable with that seen with placebo. ${ }^{1}$ In contrast, oral antihistamine administration is associated with a greater potential for systemic adverse effects. Clinical trials have shown that the most frequent adverse event seen in cetirizine-treated patients is sedation, ${ }^{12}$ with fatigue and somnolence each reported by $4 \%$ of patients who received this oral antihistamine in the present trial.

In conclusion, topical levocabastine appears to be as effective and well tolerated as cetirizine for the treatment of perennial allergic rhinoconjunctivitis with the advantage of a significantly faster onset of action. These findings suggest that levocabastine eye drops and nasal spray may be considered as an alternative to oral antihistamine therapy as a primary treatment option for patients with this condition.

\section{References}

1. Dechant KL, Goa KL. Levocabastine: a review of its pharmacological properties and therapeutic potential as a topical antihistamine in allergic rhinitis and conjunctivitis. Drugs 1991; 41: 202-224.
2. Palma-Carlos AG, Palma-Carlos ML, Rombaut N. The effect of levocabas tine nasal spray in nasal provocation tests. Int J Clin Pbarm Res 1988; 8: 25-30.

3. Rimås M, Kjellman N-IM, Blychert L-O, Björkstén B. Topical levocabastine protects better than sodium cromoglycate and placebo in conjunctival provocation tests. Allergy 1990; 45: 18-21.

4. Stokes TC, Feinberg G. Rapid onset of levocabastine eye-drops in hista mine-induced conjunctivitis. Clin Exp Allergy 1993; 23: 791-794.

5. Tomiyama S, Ohnishi $M$, Okuda $M$. The dose and duration of effect of levocabastine, a new $\mathrm{H}_{1}$-receptor antagonist, on nasal provocation reac tion to allergen. Am J Rhinol 1993; 7: 85-88.

6. Bahmer FA. Topical levocabastine-an effective alternative to oral ant histamines in seasonal allergic rhinoconjunctivitis. Clin Exp Allergy 1995; 25 (3): $220-227$

7. Bahmer FA, Ruprecht KW. Safety and efficacy of topical levocabastine compared with oral terfenadine. Ann Allergy 1994; 72: 429-434.

8. Søhoel P, Freng BA, Kramer J, et al. Topical levocabastine compared with oral terfenadine for the treatment of seasonal allergic rhinoconjunctivitis. J Allergy Clin Immunol 1993; 92: 73-81.

9. The Livostin Study Group. A comparison of topical levocabastine and oral terfenadine in the treatment of allergic rhinoconjunctivitis. Allergy 1993; 48: $519-524$.

10. The Swedish GP Allergy Team. Topical levocabastine compared with ora loratadine for the treatment of seasonal allergic rhinoconjunctivitis. Allergy 1994; 49: 611-614.

11. Badhwar AK, Druce HM. Allergic rhinitis. Clin Allergy 1992; 76: 789-803.

12. Sheffer AL, Samuels LL. Cetirizine. Antiallergic therapy beyond traditional $\mathrm{H}_{1}$ antihistamines. J Allergy Clin Immunol 1990; 86: 1040-1046.

13. Mansmann HC, Altman RA, Berman BA, et al. Efficacy and safety of cetir izine therapy in perennial allergic rhinitis. Ann Allergy 1992; 68: 348 353

ACKNOWLEDGEMENTS. This work was supported by a grant from Janssen Research Foundation, Beerse, Belgium.

The authors wish to acknowledge the assistance of the following investigators: Belgium: Members of the Janssen Research Group of General Practitioners; J. Colin, J. De Coster, E. Decaestecker, T. Degroote, K. Dupont, H. Duprez, L. Geudens, G. Nuytten, D. Paepe, H. Proost, I. Roovers, W. Spaepen, G. Vandervoort, J. Vandeweerdt, H. Visser, E. Willaert. Denmark: E. W. Eriksen, K. L. Jepsen, N. P. Jepsen, H. C. Risborg, J. Solgaard, P. Thoft-Christensen, S. Vejl, S. Winther The Netherlands: J. C. Boddeus, R. J. de Vos, H Ferguson, P. J. W. M. Fuhring, H. J. Hazelhorst, P. A van Kampen, H. A. Munnik, F. B. Naber, C. R. E. Purvis, W. M. Steenhuisen, J. van't Wout, M. J. M. A. van Sint Fiet, H. D. M. Versteegh, P. A. J. Wolter. 


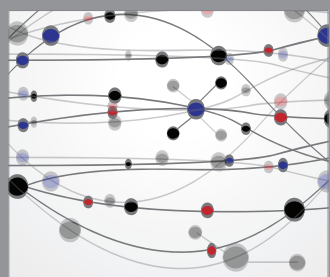

The Scientific World Journal
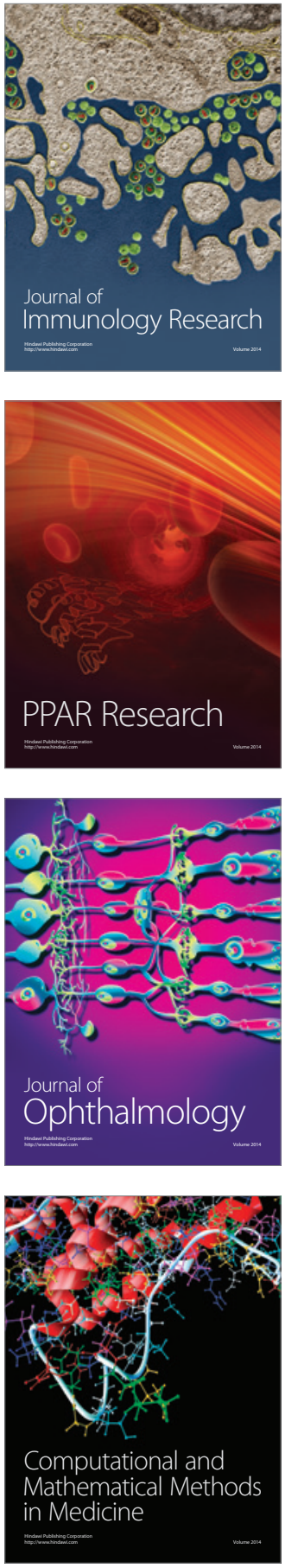

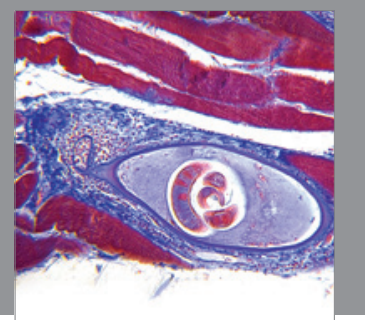

Gastroenterology

Research and Practice
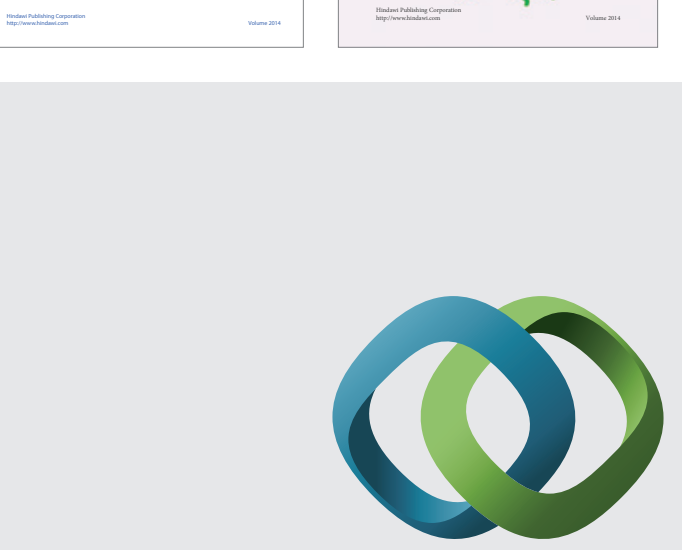

\section{Hindawi}

Submit your manuscripts at

http://www.hindawi.com
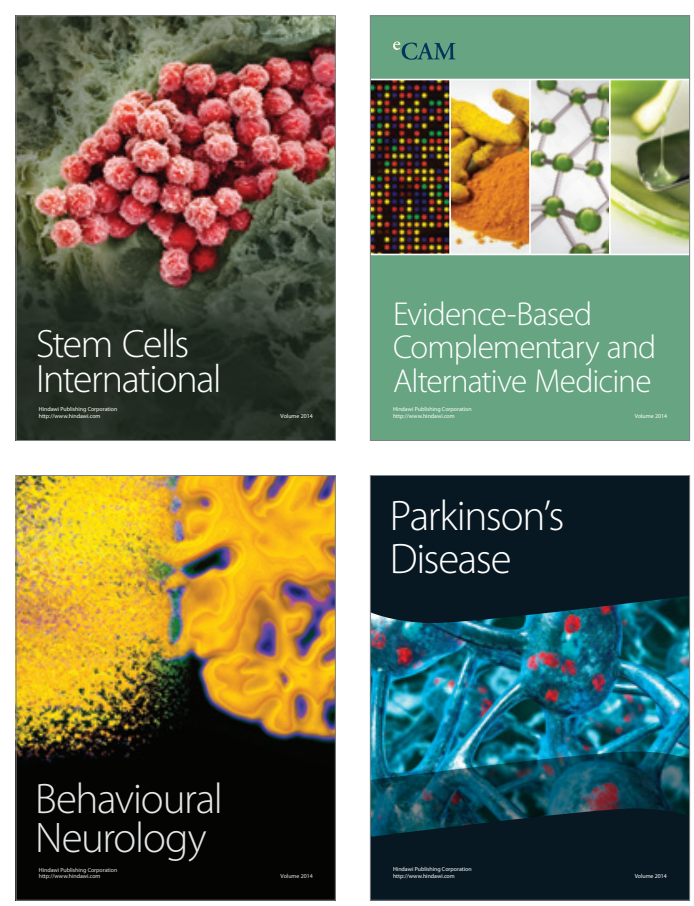

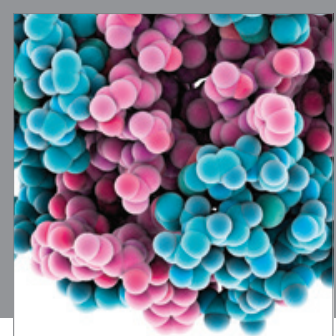

Journal of
Diabetes Research

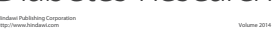

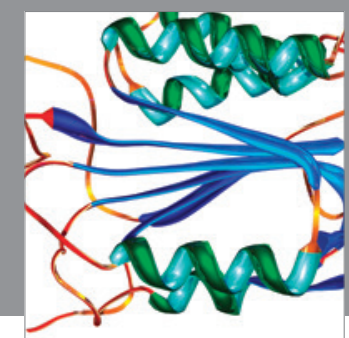

Disease Markers
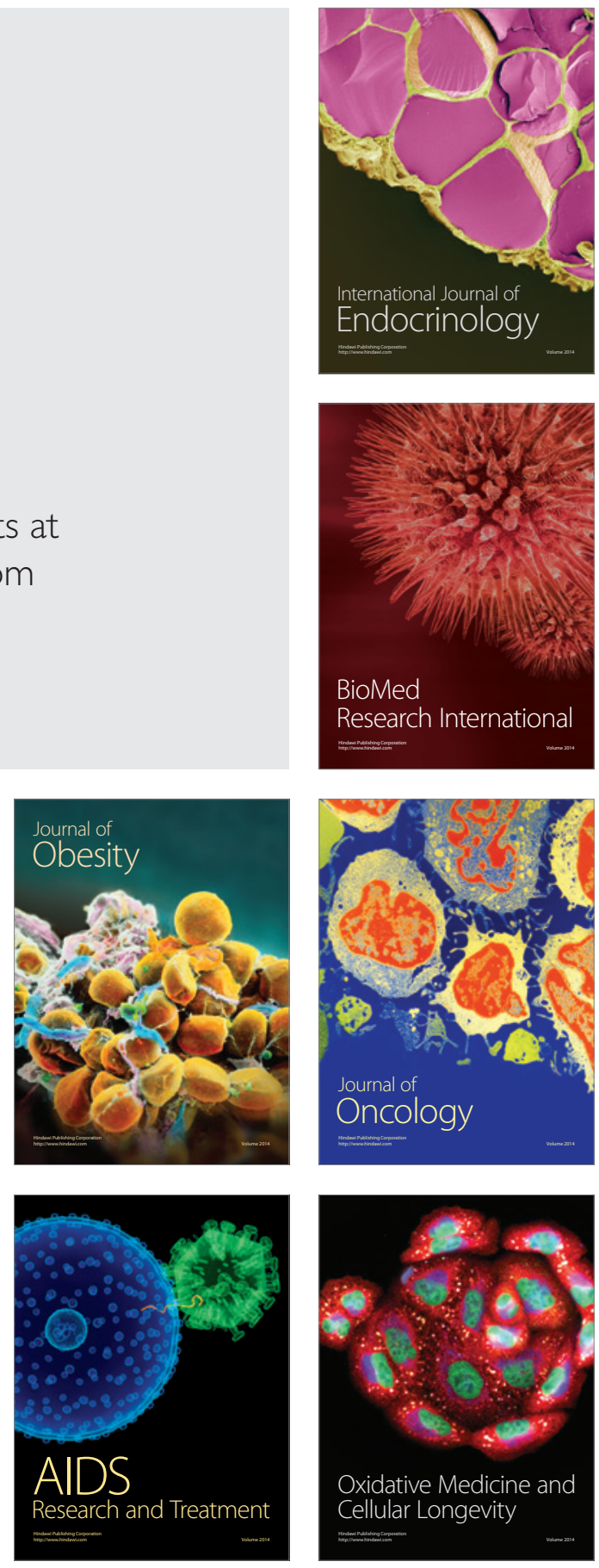